' Pyke DA, Leslie RDG. Chlorpropamide-alcohol flushing: a definition of its relation to non-insulin-dependent diabetes. $B r$ Med $\mathcal{F} 1978$;ii : 1521-2.

? Barnett AH, Pyke DA. Chlorpropamide-alcohol flushing and large-vessel disease in non-insulin-dependent diabetes. $\mathrm{Br}$ Med F 1980;281:261-2.

${ }^{3}$ Jerntorp P, Almér L-O. Chlorpropamide-alcohol flushing in relation to macroangiopathy and peripheral neuropathy in non-insulin dependent diabetes. Acta Med Scand 1981;suppl 656:33-6.

- Hill RE, Creciolo J. Determination of serum tolbutamide and chlorpropamide by high-performance liquid chromatography. $\mathcal{F}$ Chromatogr $1978 ; 145: 165-8$

${ }^{5}$ Jerntorp P, Almér L-O, Melander A. Is the blood chlorpropamide concentration critical in chlorpropamide-alcohol flush? Lancet $1981 ; \mathrm{i}$ : $165-6$

(Accepted 14 February 1983)

Department of Medicine, University Central Hospital of Kuopio, Kuopio, Finland

M LAAKSO, MD, assistant physician

K NUORVA, medical studen

A ARO, MD, associate chief

$M$ UUSITUPA, $M D$, lecturer in medicine

O SIITONEN, MD, lecturer in medicine

Department of Pharmacology, University of Turku, Finland

R HUUPPONEN, MD, research assistant

Correspondence to: Dr Markku Laakso, Department of Medicine, University Central Hospital of Kuopio, 70210 Kuopio 21, Finland.

\section{Bronchoconstriction in response to ipratropium bromide}

Ipratropium bromide is a new anticholinergic compound that is used increasingly to treat patients with limited airflow obstruction. Paradoxically, however, it may cause bronchoconstriction in occasional patients with atopic asthma. ${ }^{1}$ It has been suggested that this bronchoconstrictor response may result from increased viscosity of sputum in the airways ${ }^{1}$ or perhaps from altered bronchial reactivity to anticholinergic drugs in these patients. ${ }^{2}$ We report on a patient with extrinsic bronchial asthma who responded adversely to inhaled ipratropium bromide. We challenged the patient with two concentrations of ipratropium bromide and compared the effects with those of inhaled isotonic saline, atropine methonitrate, and sodium bromide solution to investigate the mechanism concerned.

\section{Case report}

While participating in a pharmacological study a 34 year old woman with atopic asthma and eczema developed pronounced and prolonged bronchoconstriction after inhalation of ipratropium bromide nebuliser solution ( $1 \mathrm{~g} / \mathrm{l}$ isotonic saline) given through a Wright nebuliser. Her asthma was well controlled with sodium cromoglycate $20 \mathrm{mg}$ four times a day, and she used salbutamol aerosol $200 \mu \mathrm{g}$ as required for symptomatic relief. All her drugs had been stopped 12 hours previously.

She was asked to attend on five afternoons after having stopped her drugs for at least 12 hours. Forced expiratory volume in one second was recorded with a water sealed spirometer (Godart Pulmotest). After a stable baseline reading had been obtained she was made to inhale ipratropium bromide $(0.25 \mathrm{~g} / 1$ or $1 \mathrm{~g} / \mathrm{l})$, atropine methonitrate $(10 \mathrm{~g} / \mathrm{l})$, sodium bromide $(0 \cdot 25 \mathrm{~g} / \mathrm{l})$, or isotonic saline through a Wright nebuliser at tidal breathing for five minutes. Ipratropium bromide, atropine, and sodium bromide were all dissolved in isotonic saline, and treatments were carried out in a single blind fashion. Forced expiratory volume in one second was recorded at one, three, four, seven, 10, 15, 20, 25, and 30 minutes after inhalations. She developed severe bronchoconstriction after inhaling ipratropium bromide (at both concentrations) and sodium bromide; isotonic saline did not cause any change from the baseline value of forced expiratory volume in one second (figure). Bronchodilatation occurred after inhalation of atropine methonitrate, $\stackrel{\text { w }}{\sim}$ the maximal increase in forced expiratory volume in one second being $33 \%$ at 20 minutes; this increase was still present at 30 minutes.

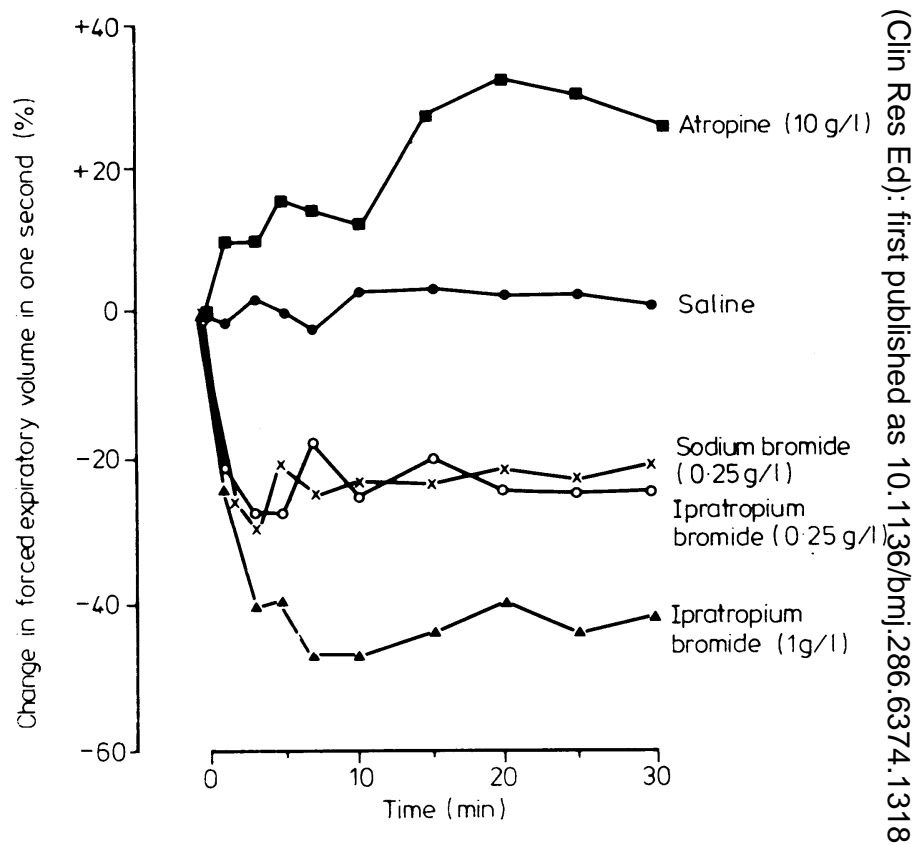

Percentage change in forced expiratory volume in one second after inhalationo of ipratropium bromide, atropine methonitrate, sodium bromide, and saline.

\section{Comment}

This patient developed bronchoconstriction within a minute afterc inhaling ipratropium bromide, with an appreciable fall in the forced $\square$ expiratory volume in one second. A similar response was observedo after challenge with sodium bromide solution. In contrast, she showed bronchodilatation after inhaling atropine methonitrate. The broncho- $\overline{0}$ constrictor response to ipratropium bromide was unlikely to haveô been due to changes in sputum viscosity or an altered bronchial ${ }^{\mathbb{Q}}$

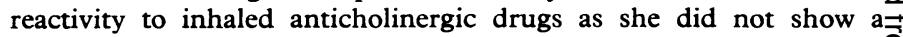
similar response to atropine. Furthermore, the drugs were dissolved in isotonic saline to avoid airways responses induced by hypotonic and hypertonic solutions. ${ }^{3}$ The bronchoconstriction was most probably related to an adverse reaction to bromide. It is difficult, however, to postulate whether bromide acts directly on the bronchial smooth muscle or the vagal receptors or causes non-specific degranulation of mast cells.

We thank Mrs Rita Jack for technical help.

1 Connolly CK. Adverse reaction to ipratropium bromide. Br Med $\mathcal{F} 1982 ;$

$285: 934-5$.
2 Jolobe OMP. Adverse reaction to ipratropium bromide. $\mathrm{Br} \mathrm{Med} \mathcal{F} 1982 ;$; 285: 1425-6.

${ }^{3}$ Schoeffel RE, Anderson SD, Altounyan RE. Bronchial reactivity in response to inhalation of ultrasonically nebulised solutions of distilledo water and saline. $\mathrm{Br}$ Med $\mathcal{f} 1981 ; 283$ :1285-7.

(Accepted 14 February 1983)

Department of Respiratory Medicine, Western Infirmary, Glasgow G11 6NT

K R PATEL, PHD, FRCP, consultant physician

W M TULLETT, MB, MRCP, medical registrar

Correspondence to: Dr K R Patel. 